crentually discussed. Is the role of science and technology now so well accepted within the Labour Party that it can be overlooked with impunity?

Mr Anthony Wedgwood Benn, formerly Minister of Technology, gave stern warnings at the end of the nationalized industries debate against moves to sell into private hands profitable public sectors such as telecommunications with its well developed research and development facilities. He said that a future Labour Government would not compensate purchasers of denationalized industries.

A seven point plan for the prevention of pollution was put forward by Nottingham Central Labour Party and, during the debate, the present Conservative Government was criticized both for making only a junior minister responsible for a matter of such basic importance and for failing to see the problem as one to be handled by long term planning. Industry, as one of the chief villains, would be considerably restricted under the Nottingham plan; factories would have to treat their effluent on site and a severe limit would be imposed on the industrial emission of sulphur dioxide. At a more personal level, the further control of vehicle exhaust and mcasures to tighten up tests on chemicals and drugs before marketing figured prominently.

\section{MEDICAL RESEARCH}

\section{MRC-University Symbiosis}

TIrE comparative affluence of the Medical Rescarch Council is leading to a shift in its role as a funding and organizing agency. Traditionally it has been a somewhat passive sponsor of research, taking the initiative whenever there was felt to be some gap in the national effort, but otherwise occupied with the care of its own units within the hospitals and universities and the provision of grants to those who came knocking on its door. The MRC is now to establish at its headquarters office a Universities, Grants and Training Awards Division with the specific objective of promoting liaison. with the universities and strengthening the more informal means of communication which already exist.

So far the MRC has not suffered as much as most agencies-including the University Grants Committee -in the limitation of funds and this makes it one of the more attractive organizations with which to liaise. None the less, there is clearly an image of remoteness to be removed, and Dr Brandon Lush, who is to head the new division, will scek to bridge this gulf. The aim is not necessarily to make it casier to gain access to the coffers of the MRC, but to tell the universitics more about the council's policics and to hear more directly about the needs of the universities.

The changes necessitate reorganization at head office. Last year saw innovation in the form of grants committees to help assess the merit of applications for support and there has always been a grants scetion at MRC headquarters. Even so, there have been signs of strain and the new division is at once a symptom of the increasing call on MRC funds and an acknowledgment of remaining inadequacy in the machinery for making awards. So long as rumours of the government's disenchantment with the rescarch councils remain unfounded, the $\mathrm{MRC}$ can hope to improve both its efficiency and its public image and extend its influence as a power in the land.

\section{COUNTRYSIDE}

\section{Save Britain's Coust}

\author{
by our Planning Correspondent
}

THIRTY-Four stretches of coast, representing the finest coastal scenery in England and Wales, have been selected by the Countryside Commission from the 2,054 miles of largely underdeveloped coastline for designation nationally as "heritage coasts". The commission wants such areas, which total some 27 per cent (730 miles) of the English and Welsh coastline, and which are all more than a mile long, to be specially managed by local authorities so that they are protected from incongruous development and from pressures imposed by too many visitors. The commission's policies for the management of these coastal areas are set out in the two final reports (The Planning of the Coastline, $17 \mathrm{~s}$ 6d; The Coastal Heritage, $£ 4$, HMSO) in its study of coastal preservation and development. These are the last of a series of reports which have been appearing since 1967 .

The commission does not want to kecp visitors away from the heritage coasts, which include the Seven Sisters and Beachy Head and the Isles of Scillyindeed it recognizes that the demands for recreation in some of its proposed special areas will be particularly heavy because of their attractions. But to reconcile these demands with the safeguarding of the area's natural scenery, there must be positive policies for management. The Coastal Heritage suggests some fundamental principles to ensure effective management. One suggestion is that the scale of recreational activities and of the provision of facilities for visitors should be related dircetly to an optimum level of use. To achieve this, each stretch of coastline should be divided into three zones with an agreed level of use. There should also be regulations of access for people and vehicles at places where an excessive concentration is likely to cause damage. Rigorous control over development, emphasis on the opportunities for different forms of recreation, and information services are also urged. Each local authority should also appoint a conservation officer who could advise a special committee on the management of the heritage coasts.

In preparing The Planning of the Coastline the commission has looked more gencrally at the English and Welsh coastline in terms of the changing patterns of holidaymaking in Britain, and the effects of these changes on the coast. In addition to recommending compact new holiday centres, it wants the government to give it powers to designate regional parks in coastal areas which offer good opportunitics for recreation, such as Chichester Harbour. The powers and organization of the authorities set up to administer these parks could, the commission suggests, be modelled on the present national parks. The commission is also critical of the eyesores which remain on the coast, in particular the colliery wastes on the foreshores of Northumberland and Durham, and defence structure in many places, and it says that target dates should be set for the removal of the messes by local authorities. The commission repeats its request, made in 1968, to look into the exploitation of reserves of gas and oil off the coast, saying that such a commission is an essential preliminary to the formulation of a national policy on the planning aspects of these industries. 